ISSN 1112-9867

\title{
CULTIVATION OF CHLORELLA VULGARIS IN PHOTOBIOREACTOR BY USING COMPOST AS A NUTRIENT SOURCE FOR BIOMASS PRODUCTION
}

\author{
X. B. $\operatorname{Tan}^{1}$, Y. Uemura ${ }^{1}$, J. W. $\operatorname{Lim}^{2}$ and M. K. Lam ${ }^{1, *}$ \\ ${ }^{1}$ Chemical Engineering Department, UniversitiTeknologi PETRONAS, 32610 Seri Iskandar, \\ Perak, Malaysia \\ ${ }^{2}$ Fundamental and Applied Science Department, UniversitiTeknologi PETRONAS, 32610 \\ Seri Iskandar, Perak, Malaysia
}

Published online: 10 November 2017

\begin{abstract}
Microalgae are well known for its high photosynthetic activity and ability to accumulate large amount of lipids within their cells. Compost fertilizers are derived from manure or food wastes which contain high concentration of nutrients such as nitrogen and phosphate. Hence, this study was to investigate the potential of compost nutrient derived from different feedstock to grow microalgae and to optimize the biomass production from microalgae via batch cultivation method. The optimized parameter were such as $\mathrm{pH}$, amount of nutrient added and types of compost used. Chlorella vulgaris was favored to grow under the condition of $0.04 \mathrm{~L} / \mathrm{L}$ of chicken compost added in and $\mathrm{pH} 3,6$ and 7. To this extent, this will able to reduce the energy usage and cost saving.
\end{abstract}

Keywords: chlorella vulgaris; compost; batch culture; biomass.

Author Correspondence, e-mail: lam.mankee@utp.edu.my

doi: http://dx.doi.org/10.4314/jfas.v9i6s.23 


\section{INTRODUCTION}

Fossil fuels are a valuable one-time energy gift to the human race. Once it is depleted, humankind has to find other alternative energy. In 2008, the annual world primary energy consumption was estimated at around 11,295 million tonnes of oil equivalent [1-2]. In [10] reported that heavy relying on fossil fuels will cause shortage of energy and emissions of greenhouse gases to the environment. Therefore, renewable energy has become an important energy sources to replace current fossil fuels. The renewable energy such as wind, solar and biofuel is environmentally friendly energy sources and help to reduce the greenhouse gas emission [3-4].

Currently, microalgae are considered as one of the most promising feedstock for biodiesel production. This is because microalgae can reproduce rapidly due to their simple cellular structure and high lipid productivity [5- 8].

Normally, chemical or inorganic fertilizer is used as the nutrient sources for microalgae cultivation. However, inorganic fertilizers are usually released to the environment as a result of domestic, agricultural and industrial water activities. This has subsequently caused eutrophication pollution to the receiving water bodies [9].

Microalgae cultivation requires large amount of fertilizers, causing high costs are needed during operation and adverse environmental effects by leaking the nutrients to the environment [10]. Alternatively, compost derived from waste can be used to cultivate microalgae. Cultivating microalgae by using compost as the nutrients can minimize the energy used. Since compost contains high concentration of nutrient such as nitrate and phosphate $[3,11]$, these nutrient sources are an excellent way to promote the growth of microalgae and to economically improve microalgae biodiesel production [10-12]. Alternatively, it is also possible to fulfil the nutritional requirements. Compost contains abundant of organic material. Therefore, it is able to improve the soil to withstand the stresses and assist the crop to uptake more nutrient. Besides that, it poses an active nutrient cycling capacity due to vigorous microbial activity.

Cultivation of microalgae cells are usually influenced by $\mathrm{pH}$, amount of nutrient added and types of compost. Therefore, this research is undertaken to investigate the potential of compost nutrient derived from different feedstock to grow microalgae and to optimize its 
biomass production via batch cultivation method by varying different parameters such as $\mathrm{pH}$, amount of nutrient added in and types of the compost used.

\section{RESULTS AND DISCUSSION}

Before the cultivation experiment started, a correlation between the optical density of Chlorella vulgaris and biomass concentration was carried out. The optical density was measured daily at $688 \mathrm{~nm}$ by using spectrophotometer. $15 \mathrm{ml}$ of the sample was taken out from the cultivation medium and the sample was measured by using UV-vis spectrophotometer (UV-VIS 3600, SHIMADZU). Then, the sample was centrifuged by using centrifuge machine and the top layer of the supernatant was removed and the remaining biomass was put into the oven at temperature $105^{\circ} \mathrm{C}$ for 24 hours. Then, the weight of the microalgae biomass was measured. The correlation is shown in Fig.1.

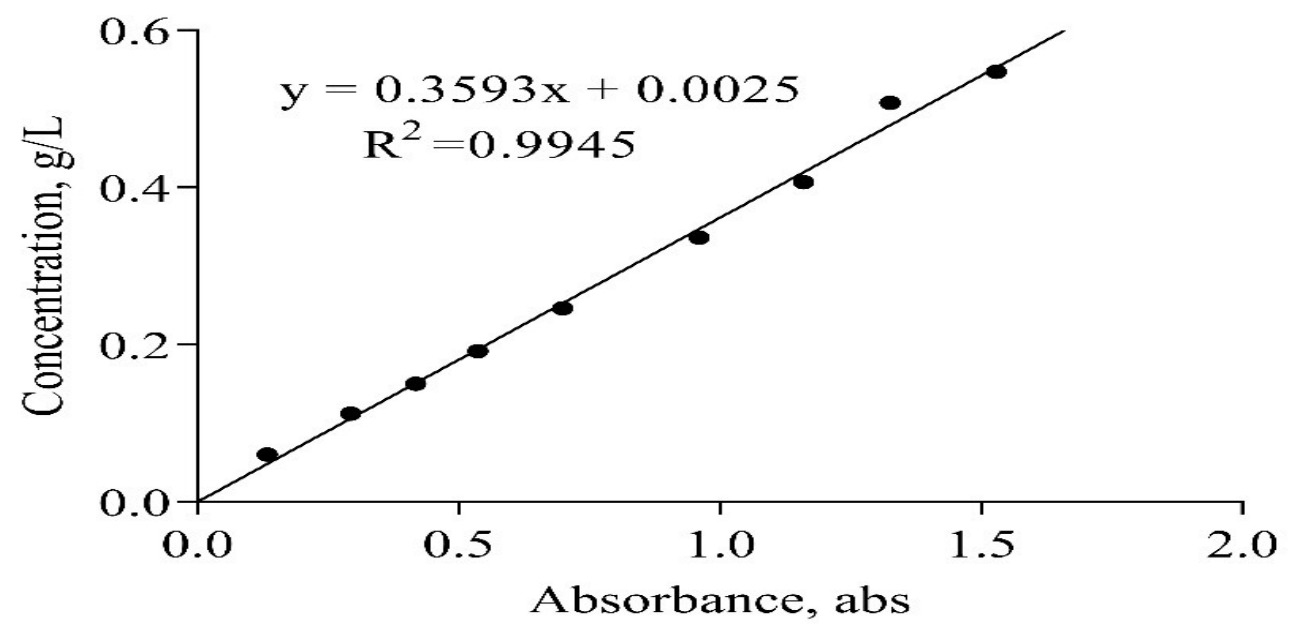

Fig.1. Calibration curve

Fig. 2 indicated the effect of different compost sources namely chicken, goat and plant compost towards the growth of Chlorella vulgaris at the pre-determined $\mathrm{pH}$ and amount of compost nutrient. From the figure, the growth of Chlorella vulgaris was strongly affected by different types of compost used. The highest biomass yield attained was $0.8 \mathrm{~g} / \mathrm{L}$ when the microalgae were cultivated with chicken compost for 12 days. On the other hand, for goat compost and plant compost, the biomass yield attained was around $0.4 \mathrm{~g} / \mathrm{L}$ and $0.6 \mathrm{~g} / \mathrm{L}$ respectively which was lower compared with chicken compost. This is due to the reason that 
chicken compost contains more complete vital nutrients concentration compared to the goat and plant compost Table 1. The goat compost consisted of high concentration of potassium and possibly causes the culture medium to become more saline and resulted slow growth of freshwater type Chlorella vulgaris. Meanwhile, plant compost contains less macronutrients and micronutrient than chicken compost such as nitrogen $(2 \%)$ and boron $(25.4 \mathrm{mg} / \mathrm{kg})$. Hence, the growth of microalgae in plant compost was slower than in chicken compost but higher than goat compost. Then, the specific growth rate of chicken compost $\left(0.1628\right.$ day $\left.^{-1}\right)$ was the highest compared with goat compost $\left(0.0631\right.$ day $\left.^{-1}\right)$ and plant compost $\left(0.1376\right.$ day $\left.^{-1}\right)$. Three different type of composts (chicken, goat and plant) showed significant difference which was the $\mathrm{P}<0.05$ in the growth of Chlorella vulgaris.
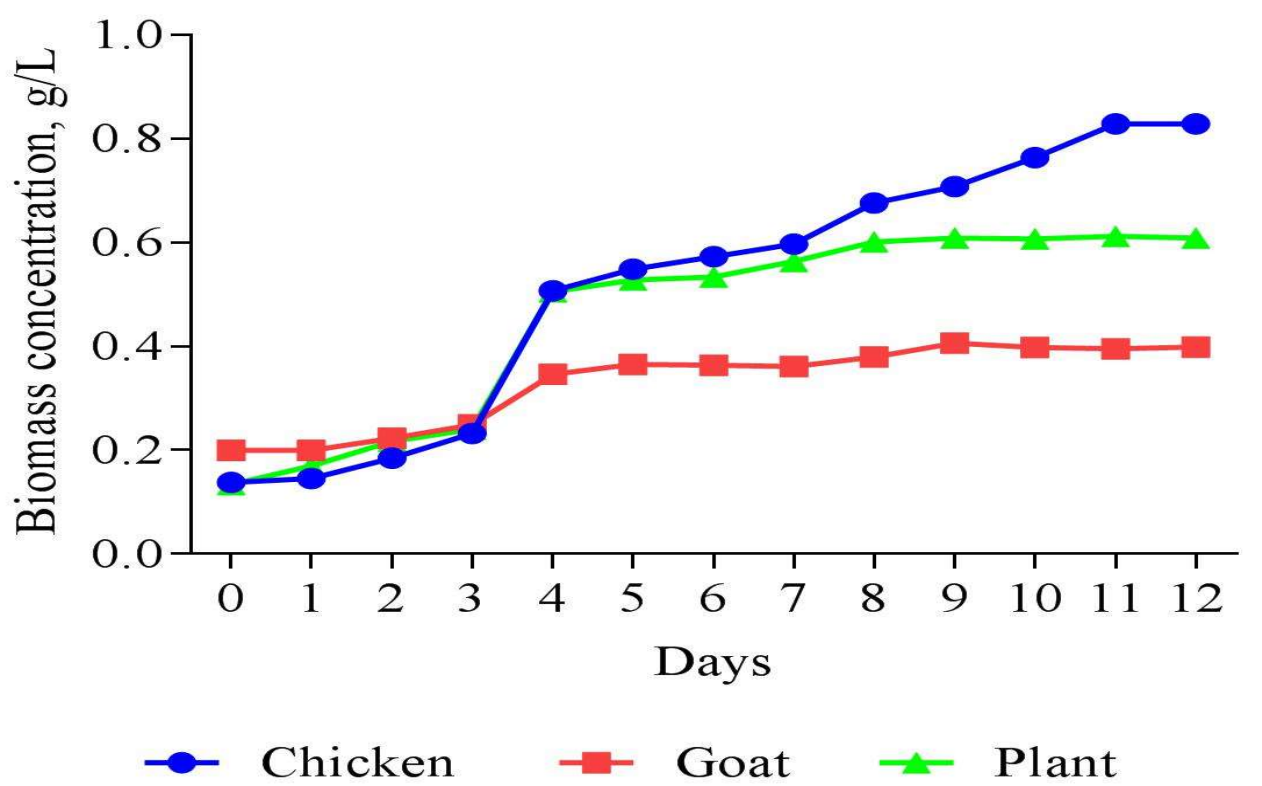

Fig.2. Effect of different nutrient for cultivating Chlorella vulgaris at predetermined $\mathrm{pH}$ and amount of nutrient

Fig. 3 showed effect of $\mathrm{pH}$ for Chlorella vulgaris growth at pre-determined amount of chicken compost. From the figure, Chlorella vulgaris growth was almost linear at the $\mathrm{pH} \mathrm{3,6}$ and 7 with the biomass yield of $0.8 \mathrm{~g} / \mathrm{L}$ after 12 days cultivation. However, the microalgae could not grow well at $\mathrm{pH} 8$. This may be due to the microalgae were unable to adapt at the $\mathrm{pH} 8$ compared with $\mathrm{pH} 3,6$ and 7. Therefore, the specific growth rate of Chlorella vulgaris at $\mathrm{pH} 8$ $\left(0.1502\right.$ day $\left.^{-1}\right)$ was lower compared to the growths at $\mathrm{pH} 3,6$ and $7\left(0.1673\right.$ day $^{-1}, 0.1726$ 
day $^{-1}$ and 0.1752 day $^{-1}$ respectively). The advantage to grow Chlorella vulgaris under acidic condition is that it can eliminate naturally biotic contaminants natural. On the other hand, there was no significant increment of microalgae biomass in the medium at $\mathrm{pH} 10$ after 12 days cultivation. The biomass of microalgae was around $0.1 \mathrm{~g} / \mathrm{L}$ and the specific growth rate was the lowest compared with others which was -0.0072 day $^{-1}$. The $\mathrm{pH}$ parameter showed significant difference which was $\mathrm{P}<0.05$ in the microalgae (Chlorella vulgaris) growth.

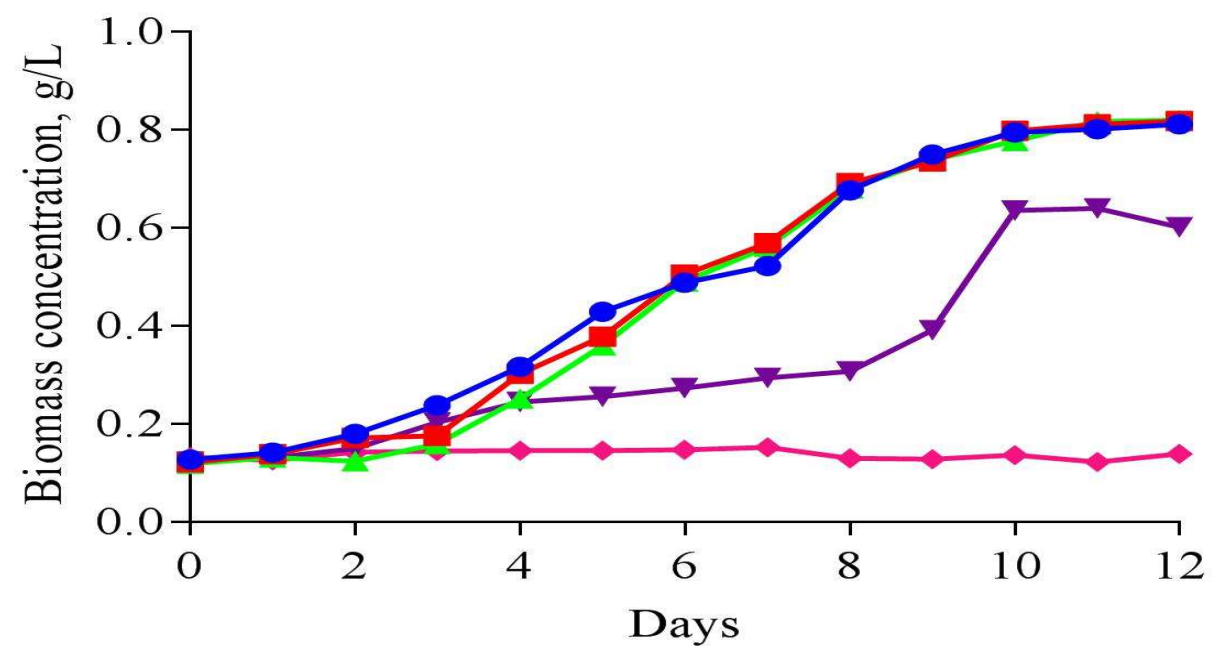

$\multimap \mathrm{pH} 3 \rightarrow \mathrm{pH} 6 \multimap \mathrm{pH} 7 \rightarrow \mathrm{pH} 8 \multimap \mathrm{pH} 10$

Fig.3. Effect of $\mathrm{pH}$ for Chlorella vulgaris growth at pre-determined amount of chicken compost

Fig. 4 represented the effect of amounts of compost nutrients added into the culture medium of Chlorella vulgaris at pre-determined $\mathrm{pH}$. From the figure, Chlorella vulgaris growths were quite stable and almost linear at the condition of different amount of nutrient added into culture medium. However, Chlorella vulgaris grew much better with $0.04 \mathrm{~L} / \mathrm{L}$ of nutrient added in the culture medium. The biomass generate was around $0.9 \mathrm{~g} / \mathrm{L}$, which was better than others. Besides that, the specific growth rate of Chlorella vulgaris with $0.04 \mathrm{~L} / \mathrm{L}$ nutrient added in culture medium was 0.1824 day $^{-1}$. The specific growth rate for $0.01 \mathrm{~L} / \mathrm{L}, 0.02 \mathrm{~L} / \mathrm{L}$, $0.03 \mathrm{~L} / \mathrm{L}$ and $0.05 \mathrm{~L} / \mathrm{L}$ of nutrients added into the culture medium for cultivating microalgae were 0.1488 day $^{-1}, 0.15738$ day $^{-1}, 0.1596$ day $^{-1}$ and 0.1660 day $^{-1}$ respectively. These results showed that high amount of nutrient in the culture medium can promote the microalgae growth and subsequently attain higher biomass yield. The amount of the compost nutrients 
added into the culture medium of Chlorella vulgaris showed the significant difference which was $\mathrm{P}<0.05$ in the growth of Chlorella vulgaris.

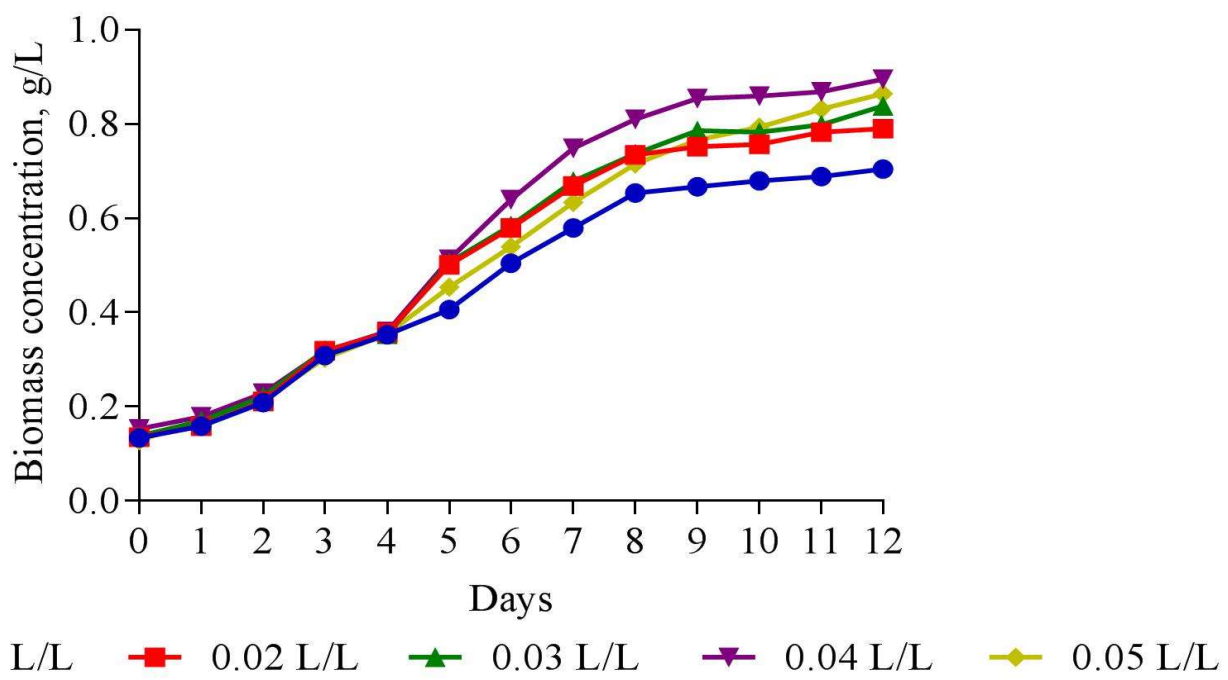

Fig.4. Effect of amount of nutrients add into culture medium of Chlorella vulgaris at pre-determined $\mathrm{pH}$

\section{METHODOLOGY}

Chlorella vulgaris were obtained from Prof. Lee KeatTeong (School of Chemical Engineering, UniversitiSains Malaysia). The microalgae was preserved and grown in Bold's Basal Medium (BBM) consisting of: (1) $10 \mathrm{~mL}$ perliter of culture medium with the following chemicals: $\mathrm{NaNO}_{3}(25 \mathrm{~g} / \mathrm{L}), \mathrm{CaCL}_{2} .2 \mathrm{H}_{2} \mathrm{O}(2.5 \mathrm{~g} / \mathrm{L}), \mathrm{MgSO}_{4} .7 \mathrm{H}_{2} \mathrm{O}(7.5 \mathrm{~g} / \mathrm{L}), \mathrm{K}_{2} \mathrm{HPO}_{4}(7.5 \mathrm{~g} / \mathrm{L}), \mathrm{KH}_{2} \mathrm{PO}_{4}$ $(17.5 \mathrm{~g} / \mathrm{L}), \mathrm{NaCl}(2.5 \mathrm{~g} / \mathrm{L})$ and (2) $1 \mathrm{~mL}$ per liter of culture medium with the following chemicals: EDTA anhydrous (50 g/L), KOH (31 g/L), FeSO $4.7 \mathrm{H}_{2} \mathrm{O}(4.98 \mathrm{~g} / \mathrm{L}), \mathrm{H}_{2} \mathrm{SO}_{4}(1 \mathrm{~mL})$, $\mathrm{H}_{3} \mathrm{BO}_{3}(11.4 \mathrm{~g} / \mathrm{L}), \mathrm{ZnSO}_{4} .7 \mathrm{H}_{2} \mathrm{O}(8.82 \mathrm{~g} / \mathrm{L}), \mathrm{MnCl}_{2} .4 \mathrm{H}_{2} \mathrm{O}(1.44 \mathrm{~g} / \mathrm{L}), \mathrm{O}_{3}(0.71 \mathrm{~g} / \mathrm{L})$, $\mathrm{CuSO}_{4} .5 \mathrm{H}_{2} \mathrm{O}(1.57 \mathrm{~g} / \mathrm{L}), \mathrm{Co}\left(\mathrm{NO}_{3}\right)_{2} .6 \mathrm{H}_{2} \mathrm{O}(0.49 \mathrm{~g} / \mathrm{L})$. The initial $\mathrm{pH}$ of the medium was adjusted to 3.0 to 3.5. The seed culture was grown in a $5 \mathrm{~L}$ Duran bottles containing $500 \mathrm{~mL}$ of culture medium, aeration with compressed air, surrounding temperature ranging from 25-28 ${ }^{\circ} \mathrm{C}$ and illuminate with cool white fluorescent light (Philip TL-D $36 \mathrm{~W} / 865$, light intensity of 60-70 $\mu \mathrm{molm}^{-2} \mathrm{~s}^{-1}$ ) continuously.

\subsection{Compost Nutrients Preparation}

$10 \mathrm{~g}$ of each of the compost was immersed in $600 \mathrm{~mL}$ tap water and stirred for $24 \mathrm{~h}$ using 
magnetic stirrer. Non-soluble particulate solids were observed after the stirring process and were filtered by using filter paper (Double Rings 101). The resulting organic fertilizer or compost medium was dark-brown in colour. Table 1 shows the characteristics of three types of composts.

Table1. Characteristics of three types of composts

\begin{tabular}{|c|c|c|c|c|c|}
\hline Test Description & Unit & Chicken & Plant & Goat & Method Used \\
\hline Nitrogen (as N) & $\% \mathrm{w} / \mathrm{w}$ & 3.3 & 2.0 & 4.0 & MS4 17: 1994 \\
\hline Phosphorus (as & $\mathrm{mg} / \mathrm{kg}$ & 20.5 & 32.8 & 19.6 & MS4 17: 1994 \\
\hline \multicolumn{6}{|l|}{$\left.\mathrm{P}_{2} \mathrm{O}_{5}\right)$} \\
\hline Potassium (as & $\mathrm{mg} / \mathrm{kg}$ & 701.6 & 543.8 & 1311.7 & MS4 17: 1994 \\
\hline \multicolumn{6}{|l|}{$\left.\mathrm{K}_{2} \mathrm{O}\right)$} \\
\hline Calcium (as & $\mathrm{mg} / \mathrm{kg}$ & 1053.7 & 499.7 & 1474.3 & MS4 17: 1994 \\
\hline \multicolumn{6}{|l|}{$\mathrm{CaO})$} \\
\hline Magnesium (as & $\mathrm{mg} / \mathrm{kg}$ & 77.0 & 124.7 & 24.9 & MS4 17: 1994 \\
\hline \multicolumn{6}{|l|}{$\mathrm{MgO})$} \\
\hline \multirow[t]{2}{*}{ Sulphur (as S) } & $\% \mathrm{w} / \mathrm{w}$ & Nil & Nil & Nil & AOAC 980.02, \\
\hline & & & & & $17^{\text {th }} \mathrm{Ed}$ \\
\hline \multirow[t]{2}{*}{ Boron $\left(\right.$ as $\left.\mathrm{B}_{2} \mathrm{O}_{3}\right)$} & $\mathrm{mg} / \mathrm{kg}$ & 46.5 & 25.4 & 44.0 & AOAC 982.01, \\
\hline & & & & & $17^{\text {th }} \mathrm{Ed}$ \\
\hline \multirow[t]{2}{*}{ Zinc (as Zn) } & $\mathrm{mg} / \mathrm{kg}$ & 9.2 & 2.7 & 3.8 & AOAC 965.09, \\
\hline & & & & & $17^{\text {th }} \mathrm{Ed}$ \\
\hline Manganese (as & ppm & Nil & Nil & Nil & AOAC 965.09, \\
\hline $\mathrm{Mn})$ & & & & & $17^{\text {th }} \mathrm{Ed}$ \\
\hline \multirow[t]{2}{*}{ Copper (as $\mathrm{Cu}$ ) } & $\mathrm{mg} / \mathrm{kg}$ & 1.0 & Nil & 1.1 & AOAC 965.09, \\
\hline & & & & & $17^{\text {th }} \mathrm{Ed}$ \\
\hline
\end{tabular}

\subsection{Cultivation of Microalgae Using Compost}

Three 5 L Duran bottles were used as photobioreactor to cultivate the microalgae. $250 \mathrm{ml}$ of the seed culture and $4750 \mathrm{ml}$ of tap water are introduced into each of the photobioreactor. 
Three different types of compost namely chicken, goat and plant compost were introduced into the three photobioreactors respectively at pre-determined amount of compost nutrient and $\mathrm{pH}$. During the experimental study, $\mathrm{pH}$ was varied from $\mathrm{pH} 1$ to $\mathrm{pH} 12$ while amount of nutrients varied from $0.01 \mathrm{~L} / \mathrm{L}$ to $0.05 \mathrm{~L} / \mathrm{L}$.

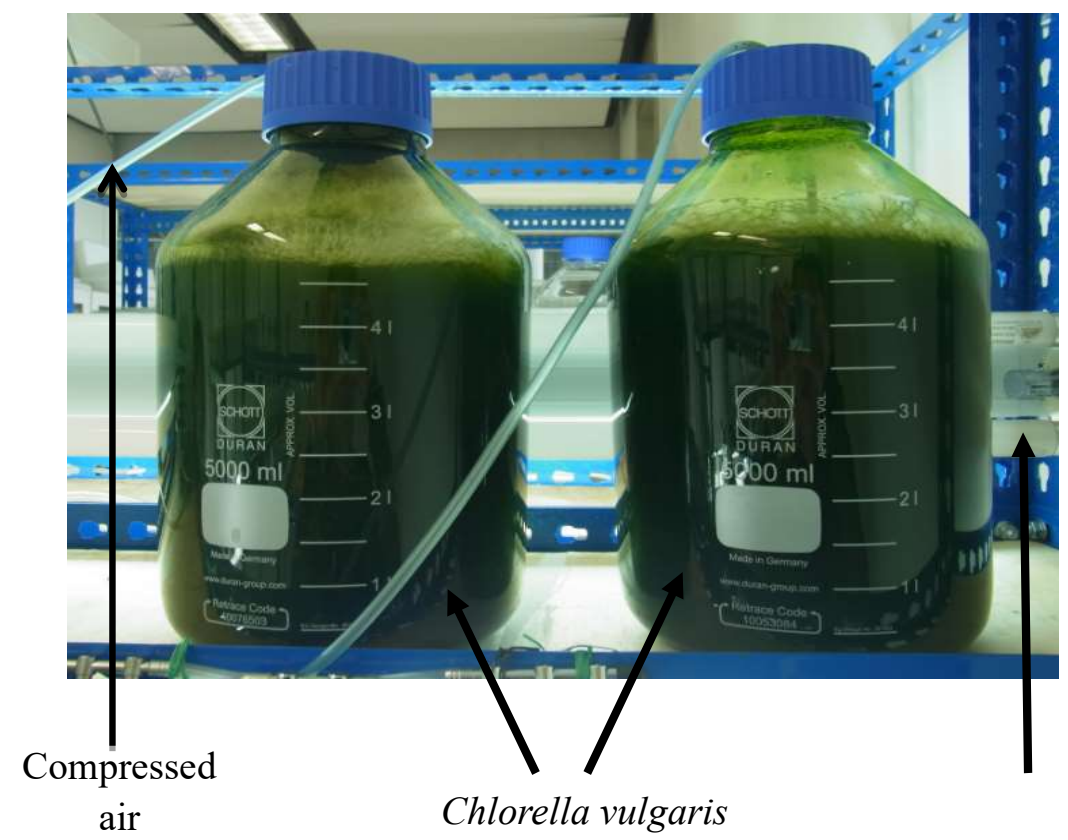

Fig.6. Five liters Duran bottle with microalgae

\subsection{Statistical Analysis}

The statistical difference were validated by analysis of variance (ANOVA) followed by Turkey Post-hoc pairwise comparison at $\mathrm{P}<0.05$ using SPSS (Statistical Package for the Social Sciences) Statistical Software (IBM).

\section{CONCLUSION}

The result in this paper indicated that it is feasible to utilize chicken compost to cultivate Chlorella vulgaris for biomass production. It was found that Chlorella vulgaris was favored to grow under following condition: $0.04 \mathrm{~L} / \mathrm{L}$ chicken compost and $\mathrm{pH} 3$.

\section{ACKNOWLEDGEMENTS}

The authors would like to acknowledge the financial support from Ministry of Higher Education Malaysia (FRGS with cost center 015AB-L25). The authors are deeply grateful to 
Prof. Lee KeatTeong (School of Chemical Engineering, UniversitiSains Malaysia) for providing the microalgae.

\section{REFERENCES}

[1] Brennan L, Owende P. Biofuels from microalgae-A review of technologies for production, processing, and extractions of biofuels and co-products.Renewable and Sustainable Energy Reviews, 2010, 14(2):557-577

[2] Darzins A, Pienkos P, Edye L. Current status and potential for algal biofuels production. $\begin{array}{lll}\text { IEA } & \text { Bioenergy 2010, }\end{array}$ http://citeseerx.ist.psu.edu/viewdoc/download?doi=10.1.1.469.1364\&rep=rep1\&type=pdf

[3]Lam MK, Lee K T. Microalgae biofuels: A critical review of issues, problems and the way forward. Biotechnology Advances, 2012, 30(3):673-690

[4]Huang G, Chen F, Wei D, Zhang X, Chen G. Biodiesel production by microalgal biotechnology.Applied Energy, 2010, 87(1):38-46

[5]Lam MK, Lee KT. Potential of using organic fertilizer to cultivate Chlorella vulgaris for biodiesel production. Applied Energy, 2012, 94:303-308

[6] de Oliveira FMF, Crispim MCB. Compost extract as a nutrient source for algal cultures. Journal of Aquaculture Research and Development, 2013, 4(5):1-4

[7]Lim H. C., Shin H. S. Fed-batch cultures: Principles and applications of semi-batch bioreactors. England: Cambridge University Press, 2013

[8]Lam MK, Lee KT. Cultivation of Chlorella vulgaris in a pilot-scale sequential-baffled column photobioreactor for biomass and biodiesel production. Energy Conversion and Management, 2014, 88:399-410

[9] Abdel-Raouf N, Al-Homaidan A, Ibraheem I. Microalgae and wastewater treatment. Saudi Journal of Biological Sciences, 2012, 19(3):257-275

[10] Zhu L, Hiltunen E, Li Z. Continuous production of high-value products, biodiesel and biogas from microalgae cultivated with livestock waste compost: A feasible study. International Scientific Journal Environmental Science, 2015, 4:1-4

[11] Ma F, Hanna M A. Biodiesel production: A review. Bioresource Technology, 1999, $70(1): 1-15$ 
[12] Zhou W, Chen P, Min M, Ma X, Wang J, Griffith R, Hussain F, Peng P, Xie Q, Li Y, Shi J. Environment-enhancing algal biofuel production using wastewaters. Renewable and Sustainable Energy Reviews, 2014, 36:256-269

\section{How to cite this article:}

Tan X B, Uemura Y, Lim J W, Lam M K. Cultivation of chlorella vulgaris in photobioreactor by using compost as a nutrient source for biomass production. J. Fundam. Appl. Sci., 2017, 9(6S), 288-297. 